PACS: 74.25.- -q

UDC: 538.945 .92

\title{
Capillary (Laplace) pressure and superconductivity of nano-sized crystalline particles of semimetals
}

\author{
Yu.I. Boyko ${ }^{1}$, V.V. Bogdanov ${ }^{1}$, R.V. Vovk ${ }^{1}$, B.V. Grinyov ${ }^{2}$ \\ 1 V. N. Karazin Kharkiv National University, Faculty of Physics, 4 Svobody Sq., Kharkiv 61022, Ukraine \\ 2 Institute for Scintillation Materials, National Academy of Sciences of Ukraine, 60 Nauki Ave., Kharkiv 61072, Ukraine \\ bogdanov@karazin.ua
}

ORCID: 0000-0001-9243-724X, 0000-0003-2634-3549, 0000-0002-9008-6252, 0000-0002-3299-9985

DOI: $10.26565 / 2222-5617-2020-32-04$

The possibility to the superconducting state transition at temperatures close to room temperature for nanoscale crystals of bismuth and antimony semimetals, as well as their alloys is discussed. All physical reasoning, as well as the estimates given in the paper, are based on the classical thermodynamics laws, as well as on the quantum theory of superconductivity (BCS theory) conclusions, which is based on the idea of electrons "pairing" (the Cooper pairs formation) as a result of electron-phonon interaction.

It is shown that in nanocrystalline particles internal capillary compressive stresses act, the magnitude of which is sufficient for the transformation of semimetals into metals. This transition is accompanied by a change in the energy spectrum of electrons: "non-degenerate" semiconductors become metals in which the gas of "degenerate" electrons is characterized by a low Fermi energy. The latter circumstance causes an increase in the density of electronic states and enhances the electron-phonon interaction in metallized semimetals.

As the initial chemical elements from which superconducting compounds can be synthesized under pressure, substances that allow the "collectivization" of electrons can be used. The most suitable substances for this are elements of the fifth group of the periodic system $\mathrm{Bi}, \mathrm{Sb}, \mathrm{As}$, graphite, etc. They are characterized by a slight overlap of the valence and conduction zones, which leads, on the one hand, to the fact that they remain high conductors of electricity up to the absolute zero temperature, and on the other hand, they have a significantly lower density of charge carriers compared to metals.

In addition, a specific structural state is formed in bismuth and antimony alloys at certain concentrations, which leads to a change in the nature of the phonon spectrum (the number of high-frequency phonons increases), which also enhances the electron-phonon interaction.

All these changes in the energy spectrum and structural state of semimetals make it possible for nanocrystals to transition to the superconducting state at a temperature of $\approx 300 \mathrm{~K}$. crystals.

Keywords: High-temperature superconductivity (HTSC), BCS theory, semimetals, capillary pressures, nano-

\section{Капілярний (лапласівський) тиск і надпровідність нано-розмірних кристалічних частинок напівметалів Ю.І. Бойко, В.В. Богданов, Р.В. Вовк, Б.В. Гриньов \\ Харківський національний університет імені В.Н. Каразіна, м. Свободи 4, 61022, Харків, Украӥна Інститут сцинтиляційних матеріалів НАН України, пр-т Наукі, 60, Харків 61072, Україна}

Обговорюється можливість переходу в надпровідний стан за температур, близьких до кімнатних, нанорозмірних кристалів напівметалів вісмуту і сурми, а також їх сплавів. Всі фізичні міркування, а також оцінки, наведені в роботі, засновані на законах класичної термодинаміки, а також на висновках квантової теорії надпровідності (теорії BCS), в основу якої покладено ідею "спарювання" електронів (формування куперовських пар) в результаті електрон-фононної взаємодії.

Показано, що в нано-кристалічних частинках діють внутрішні стискаючі напруги капілярного походження, величина яких достатня для перетворення напівметалів на метали. Цей перехід супроводжується зміною енергетичного спектра електронів: «невироджені» напівпровідники стають металами, в яких газ «вироджених» електронів характеризується низьким значенням енергії Фермі. Остання обставина обумовлює збільшення щільності електронних станів і підсилює електрон-фононну взаємодію в металізованих напівметалах.

(C) Boyko Yu.I., Bogdanov V.V., Vovk R.V., Grinyov B.V., 2020 
Як вихідні хімічні елементи, з яких можна синтезувати надпровідні сполуки в умовах дії тиску, можна використовувати речовини, що допускають "колективізацію" електронів. Найбільш придатними для цього речовинами $є$ елементи п'ятої групи періодичної системи $\mathrm{Bi}, \mathrm{Sb}, \mathrm{As}$, графіт і ін. Для них характерним $\epsilon$ незначне перекриття валентної зони і зони провідності, що призводить, з одного боку, до того, що вони залишаються гарними провідниками електрики аж до абсолютного нуля температури, а з іншого боку, мають значно меншу, в порівнянні з металами, густину носіїв заряду.

Крім того, в сплавах вісмуту і сурми за певних концентрацій формується специфічний структурний стан, що приводить до зміни характеру фононного спектра (збільшується кількість високочастотних фононів), що також підсилює електрон-фононну взаємодію.

Всі зазначені зміни енергетичного спектру і структурного стану напівметалів обумовлюють можливість переходу нано-кристалів в надпровідний стан при температурі $\approx 300 \mathrm{~K}$.

Ключові слова: Високотемпературна надпровідність (ВТHП), Теорія BCS, напівметали, капілярний тиск, нано-кристали.

\title{
Капиллярное (лапласовское) давление и сверхпроводимость нано-
}

\author{
размерных кристаллических частиц полуметаллов \\ Ю.И. Бойко, В.В. Богданов, Р.В. Вовк, Б.В. Гринёв \\ Харьковский начиональный университет имени В.Н. Каразина, м. Свободы 4, 61022, Харьков, Украина \\ Институт сцинтилляционных материалов НАН Украины, пр. Науки, 60, Харьков 61072, Украина
}

Обсуждается возможность перехода в сверхпроводящее состояние при температурах, близких к комнатным, нано-размерных кристаллов полуметаллов висмута и сурьмы, а также их сплавов. Все физические рассуждения, а также оценки, приведенные в работе, основаны на законах классической термодинамики, а также на выводах квантовой теории сверхпроводимости (теории BCS), в основу которой заложена идея "спаривания" электронов (формирование Куперовских пар) в результате электрон-фононного взаимодействия.

Показано, что в нано-кристаллических частицах действуют внутренние сжимающие напряжения капиллярного происхождения, величина которых достаточна для превращения полуметаллов в металлы. Этот переход сопровождается изменением энергетического спектра электронов: «невырожденные» полупроводники становятся металлами, в которых газ «вырожденных» электронов характеризуется низким значением энергии Ферми. Последнее обстоятельство обусловливает увеличение плотности электронных состояний и усиливает электрон-фононное взаимодействие в металлизированных полуметаллах.

В качестве исходных химических элементов, из которых можно синтезировать сверхпроводящие соединения в условиях действия давления, можно использовать вещества, допускающие "коллективизацию" электронов. Наиболее подходящими для этого веществами являются элементы пятой группы периодической системы Bi, Sb, As, графит и др. Для них характерным является незначительное перекрытие валентной зоны и зоны проводимости, что приводит, с одной стороны, к тому, что они остаются хорошими проводниками электричества вплоть до абсолютного нуля температуры, а с другой стороны, обладают значительно меньшей, по сравнению с металлами, плотностью носителей заряда. Кроме того, в сплавах висмута и сурьмы при определенных концентрациях формируется специфическое структурное состояние, приводящее к изменению характера фононного спектра (увеличивается число высокочастотних фононов), что также усиливает электронфононное взаимодействие.

Все указанные изменения энергетического спектра и структурного состояния полуметаллов обусловливают возможность перехода нано-кристаллов в сверхпроводящее состояние при температуре $\approx 300 \mathrm{~K}$.

Ключевые слова: Высокотемпературная сверхпроводимость (ВТСП), Теория ВСS, полуметаллы, капиллярные давления, нано-кристаллы.

\section{Introduction}

It has now been reliably established that lowdimensional crystalline particles, the size of which is characterized by an interval of values $\mathrm{R} \approx 10-100 \mathrm{~nm}$ (nano crystals), possess physical properties that are fundamentally different from the properties of their bulk analogues.

The main reasons for the uniqueness of nano-crystals properties include the following:

1) change in the structural and electronic states in the surface layer of a nano-crystal;
2) coincidence of the size of the crystalline particle $R$ with the size of the characteristic parameter that determines the physical property of the material (the mean free path of phonons or electrons $l$, the coherence length $\xi$, the de Broglie wavelength of quantum particles $\lambda$ );

3 ) significant contribution of surface energy to the total energy balance of the crystal [1-4].

An important factor directly related to an increase in the contribution of surface energy is the effect of internal (capillary) pressure in low-dimensional crystals. The magnitude of this pressure and, accordingly, the 
effectiveness of its action increase with decreasing crystal size and in the above-mentioned size range $\mathrm{R}$ for metals reaches the value $\mathrm{P} \approx 10^{7}-10^{8} \mathrm{~Pa}[5]$. Such pressure for some materials can significantly change the nature and the main parameters of their electronic energy spectrum, which in turn can cause a change in their electrical properties, in particular, cause the transition of low-dimensional crystals to the superconducting state [6].

This work is devoted to discussing the possibility of realizing such a mechanism of superconductivity using the example of nanocrystals of the fifth group of the periodic system elements (semimetals).

The entire physical backgrounds, as well as the estimates given in this paper, are based on the laws of classical thermodynamics, as well as on the conclusions of the superconductivity quantum theory (BCS theory [7]), which is based on the idea of electrons "pairing" (the appearance of Cooper pairs) as a result of electron-phonon interaction.

Note that in recent years, superconductivity has been actively studied in other low-dimensional objects (in atomic complexes) that differ from nanocrystals: clusters, films, interfaces, etc. [8-11]. In these objects, usually containing only a few tens of atoms, a special (shell) structure of the energy spectrum of electrons is found, which, ultimately, determines the specific superconductivity of these formations. The physical nature of such a mechanism of superconductivity differs from the mechanism discussed in this paper and is associated with the effect of the so-called "dimensional" quantization (topological superconductivity) [11].

\section{The nature of capillary pressure and its value in the case of nano-sized crystals}

For the first time, the term "capillary pressure" and the formula describing the magnitude of this pressure (Laplace formula) appeared in [12] when describing the thermodynamic equilibrium at the boundary of two phases separated by a curved (non-flat) surface. Obviously, the displacement of the curved boundary between two different phases is accompanied by a change in the free energy of the system. This is due to a change in the surface area of the interface, which is characterized by a certain value of the unit surface energy. Therefore, the presence of a curved boundary between two different phases determines the action of a certain force and, correspondingly, internal pressure on the surface separating the phases. This pressure is the pressure difference acting on the interface from the side of coexisting phases

$$
\Delta \mathrm{P}=\mathrm{P}_{1}-\mathrm{P}_{2}
$$

Under equilibrium conditions, the pressure is compensated by the surface tension of the interface. In order to find a quantitative relationship between the magnitude of this pressure and surface tension at the phase boundary, Laplace examined the fulfillment of the necessary conditions for establishing thermodynamic equilibrium in the system. As already indicated, this state does not imply equality of pressure on the part of both phases and is established provided that the total volume of the phases is changeless, the temperature on both sides of the interface is the same, and the chemical potentials of the phases are equal. Under these conditions, the $\Delta \mathrm{P}$ value is determined from the requirement of minimum of thermodynamic potential of the system $\Phi$ written with account of boundary energy

$$
\Phi=-\mathrm{P}_{1} \mathrm{~V}_{1}-\mathrm{P}_{2} \mathrm{~V}_{2}+\gamma \mathrm{S}
$$

Here $V_{1}$ and $V_{2}$ - the volumes of neighboring phases, $S-$ interface area between phases, $\gamma$ - the unit surface energy at the phase boundary (surface tension). A necessary condition for a minimum of $\Phi$ is the vanish of its total differential $d \Phi=0$ at $T_{1}=T_{2}$ and $V_{1}+V_{2}=$ const. $\left(T_{1}\right.$ and $T_{2}-$ phase temperatures). From this condition it follows that

$$
\mathrm{P}_{1}-\mathrm{P}_{2}=\gamma(\mathrm{dS} / \mathrm{dV})
$$

If we now take into account that at any point on the curved interphase boundary surface the equality is fairly

$$
\mathrm{dS} / \mathrm{dV}=1 / \mathrm{R}_{1}+1 / \mathrm{R}_{2}
$$

were $R_{1}$ and $R_{2}$ - are the main radii of curvature, then relation (3) can be written in form:

$$
\Delta \mathrm{P}=\gamma\left(1 / \mathrm{R}_{1}+1 / \mathrm{R}_{2}\right) .
$$

This ratio is called the Laplace formula, which describes the magnitude of the internal pressure acting on a curved interface. In the particular case of a spherical surface, when $\mathrm{R}_{1}=\mathrm{R}_{2}=\mathrm{R}$,

$$
\Delta \mathrm{P}=2 \gamma / \mathrm{R}
$$

Formula (6) is fully applicable and its feasibility is confirmed by numerous experimental data in the case of a curved liquid-gas interface. A simple example of this kind of boundary is a drop of water in equilibrium with its own saturated steam. This particular case was considered in [12]. The rationale for the applicability of the Laplace formula in the case of a different nature of the interface between two phases, in particular, the solid-gas boundary, is described in [5]. In this work, it was shown that the 
Laplace formula written in the form (6) is also valid for the solid crystalline phase, starting with the size $R_{c} \approx 10 \mathrm{~nm}$, i.e., for crystals whose size is characterized by $R>R_{c}$. For ultra low dimensional objects whose size $R<R_{c}$ should use a different (generalized) Laplace formula [5]. Note that in some special cases of atomic clusters (clusters, monatomic filaments, etc.) the capillary pressure generally ceases to act, since the very concept of a crystal disappears.

Let us quantify the capillary pressure in the case of nano-crystals, i.e., bulk crystalline particles of arbitrary shape with a characteristic size $10 \leq \mathrm{R}<100 \mathrm{~nm}$. As applied to metals and metal alloys, the typical value of the constant $\gamma$ in order of magnitude is $\approx 1 \mathrm{~J} / \mathrm{m}^{2}$. Accordingly, the desired value of the internal capillary pressure, compressing the crystalline particle of the specified size range, is characterized by the value $\approx 10^{8}-10^{7} \mathrm{~Pa}$. Such pressure can change the energy spectrum of the electronic subsystem in some materials and, thus, cause a significant change in their electrical properties. Such materials, in our opinion, are elements of the fifth group of the periodic system (semimetals) [13]. In particular, under the influence of capillary pressure of the indicated magnitude, transition to the superconducting state can be realized in nano-crystals of semimetals [6].

The discussion of the possibility of display of this effect in the case of nano-sized crystals of semimetals, as well as their solid solutions, is discussed in the next section of this paper.

\section{Change in the energy spectrum of the electronic subsystem of nanoscale crystalline particles of semimetals under the action of capillary pressure}

The following substances belong to the fifth group of the periodic system of elements: $\mathrm{Bi}, \mathrm{Sb}, \mathrm{As}$ etc. [13]. For concreteness, we consider in more detail two elements: bismuth (Bi) and antimony (Sb). Under ordinary conditions (at atmospheric pressure and room temperature), the atoms of these substances are characterized by the electronic configuration $\mathrm{S}^{2} \mathrm{P}^{3}$, and the crystalline phase being formed, by its electrical properties, occupies an intermediate position between metals and semiconductors. That is why these substances are called semimetals. They are characterized by a slight overlap of the valence and conduction zones (see Fig. 1, b). These leads, on the one hand, to the fact that semimetals are good conductors of electricity, and on the other hand, they are characterized by a much lower density of charge carriers (electrons or holes) in comparison with ordinary metals. So, in bismuth $(\mathrm{Bi})$ the electron density $(\mathrm{N} / \mathrm{V})$ at room temperature is $\approx 10^{24} \mathrm{~m}^{-3}$, and in antimony $(\mathrm{Sb}) \approx 10^{25} \mathrm{~m}^{-3}$. In addition, the electrical conductivity of these materials, unlike ordinary metals, increases with increasing temperature. These features of the electrical properties of semimetals make them similar to the so-called "nondegenerate semiconductors" [14]. However, under pressure (external or internal), semimetals can be "metallized" due to a change in the overlap of energy zones and a corresponding change in the nature of filling of energy levels with charge carriers. In this case, the process of "collectivization" of valence electrons is realized with their subsequent "degeneration" - their energy spectrum is described by the Fermi - Dirac quantum statistics [14]. As a result of such a change, semimetals in the structure of the energy spectrum of the electronic subsystem become similar to ordinary metals. However, their electrical properties differ significantly from the electrical properties of classical metals. In particular, metals formed from semimetals are characterized by a relatively low Fermi energy $\left(E_{F}\right)$ and by increased density of energy states directly near the Fermi level. From the BCS theory of

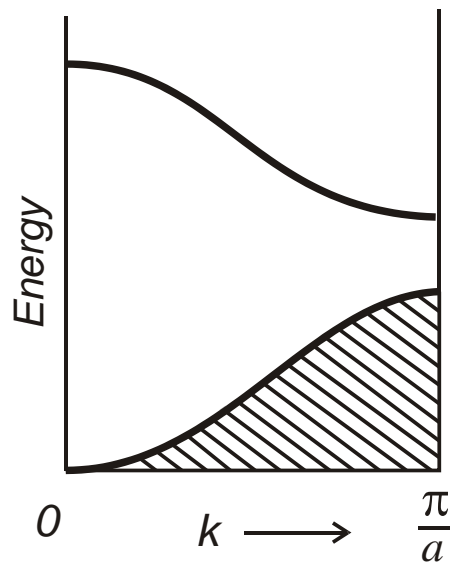

$a$

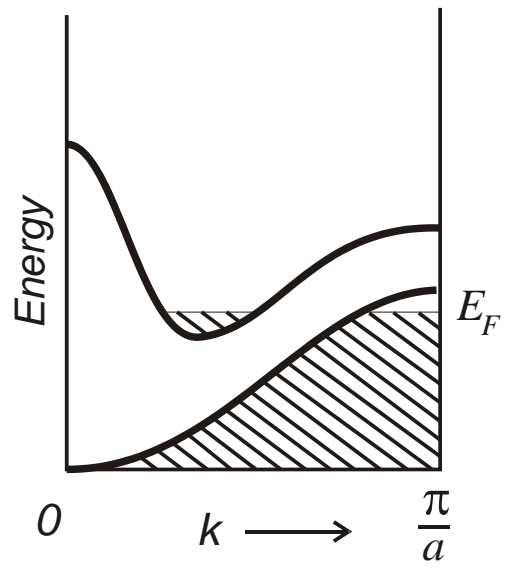

$b$

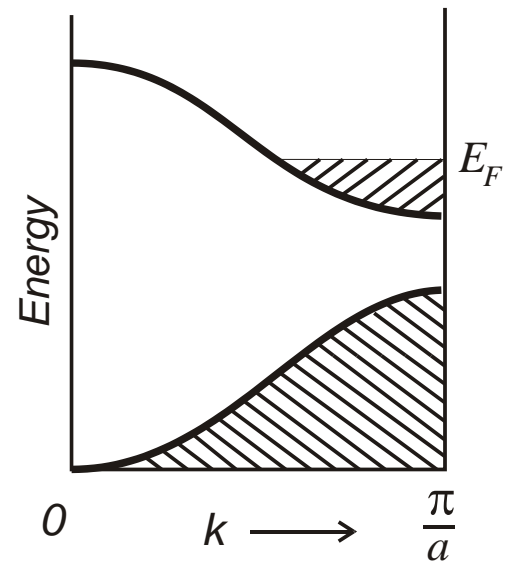

C

Fig. 1. Occupied states (shaded areas) in various zone energy structures: a) insulator, b) semimetal, c) metal. 
superconductivity point of view, it is jast this kind of the energy spectrum structure of the electronic subsystem that can cause the transition of a substance to the superconducting state. We will state the main ideas and considerations in this regard, as well as make some quantitative estimates confirming the validity of such a conclusion.

The pressure $\mathrm{P}$, under which the conversion of any solid crystalline substance (dielectric, semiconductor, semimetal) into metal can be realized, is described by the following relation $[6]$ :

$$
\mathrm{P}=0,1\left(\mathrm{~h}^{2} / \mathrm{mr}^{2}\right)(\mathrm{N} / \mathrm{V})
$$

Here $\mathrm{h}$ - Planck's constant, $\mathrm{m}$ - electron mass, $(\mathrm{N} / \mathrm{V})$ - the density of electrons to be transferred from the "nondegenerate" state to the "degenerate" inherent in all classical metals [14]. For a multi-electron atom, $r$ is the orbit radius of the electron farthest from the nucleus. Specifically for atoms Bi $\mathrm{r}=1,8 \cdot 10^{-10} \mathrm{~m}$, and for atoms $\mathrm{Sb}$ $\mathrm{r}=1,6 \cdot 10^{-10} \mathrm{~m}$. Substituting in the formula (7) the numerical values of the constants $h$ and $m$, as well as the values of $\mathrm{r}$ and $(\mathrm{N} / \mathrm{V})$, we have, respectively, for $\mathrm{Bi}$ and $\mathrm{Sb}: \mathrm{P} \approx 10^{6} \mathrm{~Pa}$ and $\mathrm{P} \approx 10^{7} \mathrm{~Pa}$. This estimate indicates that the internal capillary pressure acting on semimetal nanocrystals is sufficient for these objects to "metallize" and to realize specific changes in the structure of the electron energy spectrum.

As already indicated, a very important factor that distinguishes "metallized" semimetals from ordinary metals is the relatively small value of the Fermi energy. If for most ordinary metals that conduct electricity well $(\mathrm{Cu}$, $\mathrm{Au}, \mathrm{Al}$, etc.), the Fermi energy is characterized by an interval of values $(5-10) \mathrm{eV}$, then in the case of semimetals with artificially "collectivized" electrons, the average Fermi energy is $\approx 10^{-2} \mathrm{eV}$, i.e. more than two orders of magnitude less. This circumstance is the basis for the validity of the assertion that in the objects under discussion the electron pairing constant $\lambda$, which is the determining parameter in the BCS quantum theory of superconductivity, is characterized by $\lambda>>1$. Indeed, it follows from the theory

$$
\lambda=\mathrm{Un}_{\mathrm{s}}{ }^{*}
$$

were $\mathrm{U}$ is the potential characterizing the electron-phonon interaction, causing the "pairing" of electrons, $\mathrm{n}_{\mathrm{s}}{ }^{*}$ is the density of states in a narrow energy range $\Delta \mathrm{E}$ directly near the Fermi level. It is easy to verify that $n_{\mathrm{s}}{ }^{*} \sim 1 / \mathrm{E}_{\mathrm{F}}$ and, therefore, the pairing constant $\lambda$ in the case of nano-sized semimetal crystals, subject to capillary pressure, can increase by more than two orders of magnitude compared with the pairing constant characteristic of ordinary classical metals.

Because the experiment shows that for ordinary metal superconductors $\lambda \leq 0.3$, then in the case of nano-sized crystalline particles of semimetals this parameter can reach $\approx 10^{2}$. Such a significant increase in the pairing constant in the case of nano-sized crystals can lead to their transition to the superconducting state. This transformation can be realized at a critical transition temperature $T_{c}$ that significantly exceeds the transition temperature to this state of ordinary metal superconductors $\mathrm{T}_{\mathrm{c}} \approx(1-40) \mathrm{K}$.

Indeed, according to the theory, for charge carriers characterized by a pairing constant $\lambda>>1$, critical temperature $T_{c}$ is described by the following relation:

$$
\mathrm{T}_{\mathrm{c}} \approx 0,2 \cdot \lambda^{1 / 2} \Theta
$$

were $\Theta$ is the characteristic temperature (Debye temperature), determined by the maximum frequency $v_{m}$ of the vibration of atoms (phonons): $\Theta=\left(h v_{m}\right) / k$ ( $k$ is the Boltzmann constant). Since the Debye temperature $\theta$ for $\mathrm{Bi}$ is $\approx 10^{2} \mathrm{~K}$, and for $\mathrm{Sb} \approx 2 \cdot 10^{2} \mathrm{~K}$, then the expected critical temperature of the transition to the superconducting state of the discussed nano-scale particles of semimetals can reach values $\mathrm{T}_{\mathrm{c}} \approx\left(2 \cdot 10^{2}-4 \cdot 10^{2}\right) \mathrm{K}($ see $(9))$, i.e. close enough to room temperature $\left(\approx 23^{0} \mathrm{C}\right)$.

We also note that such an important parameter of superconductivity as the coherence length $\xi$, which is interpreted as the size of the "pairing" (Cooper) electron pairs, in the case of nano-crystals is limited to $\xi \approx 2 \mathrm{R} \approx 2 \cdot 10^{2} \mathrm{~nm}$, which does not contradict the theoretical concepts.

We emphasize that the maximum value of the critical temperature $\mathrm{T}_{\mathrm{c}}$ observed to date is $\approx 250 \mathrm{~K}$ for compound $\mathrm{LaH}_{10}$ under external pressure $\mathrm{P} \approx 170 \mathrm{GPa}$ [15]. In the case under discussion, a sufficiently high transition temperature should be observed in the absence of external pressure under the action of internal capillary pressure, the value of which $\approx 10^{8} \mathrm{~Pa}$ is more than three orders of magnitude less than the above external pressure. This circumstance greatly simplifies the use of the described superconducting materials for technical purposes.

It should be borne in mind that in addition to the "metallization" effect, a very important factor necessary for the transition to the superconducting state of semimetals is the formation of a special phonon spectrum, characterized by the presence of high-frequency phonons. We show that this condition can be realized, if we use not pure semimetals as a starting material but their solid solutions (alloys). The following paragraph of this paper is devoted to the discussion of this possibility. 


\section{Formation of additional high-frequency phonons in solid solutions $\mathrm{Bi}_{1-\mathbf{x}} \mathrm{Sb}_{\mathbf{x}}$}

Atoms $\mathrm{Bi}$ and $\mathrm{Sb}$ are characterized by a very small difference in atomic radii $(\approx 7,5 \%)$ and therefore form a continuous series of solid solutions. This is evidenced by the phase diagram, which has the form of a cigar [16]. Studies of $\mathrm{Bi}_{1-\mathrm{x}} \mathrm{Sb}_{\mathrm{x}}$ alloys with a variation in the $\mathrm{x}$ parameter indicate that at certain values of this parameter, an abrupt change in the electrical conductivity, heat capacity, thermal conductivity, etc. is observed $[17,18]$. The close correlation of changes in these properties with the variation of the $\mathrm{x}$ parameter indicates that in these alloys, a sufficiently strong electron-phonon interaction is realized. The reason for this is the specific mechanism of the crystal structure formation of the discussed solid solutions, due to the display of the so-called percolation effect $[17,19]$.

This effect is as follows. The $\mathrm{Bi}$ and $\mathrm{Sb}$ elements under normal conditions during crystallization form a crystallographic lattice of the type $\alpha-\mathrm{A}_{\mathrm{S}}\left(\mathrm{A}_{7}\right)\left(\mathrm{R} 3^{-} 2 / \mathrm{m}\right.$ space group). Atoms in this type of lattice are arranged in two parallel planes so that each atom of one plane has three nearest neighbors belonging to another plane. As a result of this specific spatial arrangement of atoms, the crystal lattice is close in its properties to a usual face-centered "pseudo-cubic" lattice. This type of crystal lattice remains the same when forming solid solutions $\mathrm{Bi}_{1-\mathrm{x}} \mathrm{Sb}_{\mathrm{x}}$. However, as shown by the results of an x-ray study, in these compounds, when the value of the parameter $\mathrm{x}$ varies, processes of additional self-organization of heterogenous atoms with respect to the crystal lattice of base matrix atoms take place (percolation effect) [19]. Upon reaching a certain value of the parameter $\mathrm{x} \approx \mathrm{x}_{\mathrm{c}}\left(\mathrm{x}_{\mathrm{c}}-\right.$ percolation threshold) at the initial stage of a solid solution forming process, low-dimensional structural elements (clusters) are formed from impurity atoms, characterized by short-range order. As the concentration of heterogenous atoms increases, the process of "crystallization" of clusters occurs, that is, the formation of a "superstructure" characterized by long-range order is occurs.

Naturally, these specific changes in the crystal structure of the compounds $\mathrm{Bi}_{1-\mathrm{x}} \mathrm{Sb}_{\mathrm{x}}$ must be accompanied by a change in the phonon spectrum with amplification of the high-frequency mode. This is indirectly evidenced by the results of the thermal properties study of the described alloys (heat capacity, thermal conductivity), as well as electrical conductivity $[17,18]$.

Therefore, there is every reason to believe that the appearance of an ordered "superstructure" in the crystal lattice of semimetal alloys should contribute to the enhancement of the electron-phonon interaction, which ultimately determines superconductivity. Note that the effect of percolation in full occurs after reaching the Вісник ХНУ імені В.Н. Каразіна, серія «Фізика», вип. 32, 2020 threshold value of the parameter $\mathrm{x}_{\mathrm{c}}$, which is $\approx 0,25$ ( $\mathrm{Bi}$ is the base element) and $\approx 0,6$ ( $\mathrm{Sb}$ is the base element).

\section{Conclusions}

Based on the analysis carried out in this work, as well as the quantitative estimates made, we can draw the following conclusions.

1. Nano-sized $(10-100 \mathrm{~nm})$ crystalline particles of semimetals can spontaneously transform into a "metallized" state under the influence of internal capillary pressure.

2. The energy spectrum of electrons formed under the capillary pressure in these objects is characterized by the appearance of a "gas" of "degenerate" electrons obeying the Fermi - Dirac quantum statistics. In this case, however, the Fermi energy of the electrons energy spectrum in the crystals under discussion is characterized by the value of $\approx 0,03 \mathrm{eV}$, which is two orders of magnitude less than the average Fermi energy of electrons in classical metals.

3. The small Fermi energy in the "metallized" nanocrystalline semimetal particles causes an increase in the pairing constant $\lambda$ to a value of $\approx 10^{2}$ i.e., these objects are characterized by strong electron-phonon interaction. Accordingly, an increase in the pairing constant should be accompanied by an increase in the critical temperature of the transition of the described substances to the superconducting state to a value $\mathrm{T}_{\mathrm{c}} \approx 300 \mathrm{~K}$.

4. In solid solutions of semimetals, when certain concentration values (percolation threshold) are exceeded, a "superlattice" of heterogenous atoms is formed. The specific structural state of the crystals being formed in this case causes a change in the nature of the phonon spectrum (an additional number of high-frequency phonons appears). This fact causes an increase in the Debye temperature $\Theta$, and also contributes to an increase in the potential of the electron-phonon interaction. Both of these factors should lead to an increase in the critical temperature $\mathrm{T}_{\mathrm{c}}$ of the discussed crystals transition to the superconducting state.

5. Thus, summing up the overall result, it can be argued that nano-sized crystalline particles of semimetals, as well as their alloys, can be superconductors with a critical transition temperature approaching room temperature $\left(\approx 23^{\circ} \mathrm{C}\right)$.

\section{References/Literature}

1. S. A. Nepijko, Fizicheskie svojstva malyh metallicheskih chastic, (Naukova dumka, Kiev, 1985), 248p. (С. А. Непийко, Физические свойства маленьких металлических частиц (Наукова думка, Киев)) [In Russian]

2. I.D. Morohov, L.I. Trusov, V.N. Lapovok, Fizicheskie yavleniya $v$ ultradispersnyh sredah, (Energoatomizdat, Moscow, 1984), 224p. (И.Д. Морохов Л.И. Трусов 
В.Н. Лаповок, Физические явления в ультрадисперсных cредаx, (Энергоатомиздат, Москва)) [In Russian]

3. R.A. Andrievski, Jornal of Material Sciens, 38, p. 1367, (2003).

4. Yu. I. Boyko, Journal of V.N. Karazin Kharkiv National University Series Physics, 651, 8, 23, (2005). (Ю. И. Бойко, Вісник ХНУ імені В.Н. Каразіна, серія «Фізика», 651, 8, 23, (2005)) [In Russian]

5. Yu. I. Boyko, Journal of V.N. Karazin Kharkiv National University Series Physics, 651, 8, 79, (2005). (Ю. И. Бойко, Вісник ХНУ імені В.Н. Каразіна, серія «Фізика», 651, 8, 79, (2005)) [In Russian]

6. Yu. I. Boyko, V.V. Bogdanov, R. V. Vovk, Low Temperature Physics, 46, 5, p. 658, (2020).

7. J. Bardeen, L. N. Cooper, J. R. Schrieffer, Phys. Rev., 108, 1175, (1957).

8. D. C. Ralh, C. T. Black, M. Tinkham, Phys. Rev., 78, 4087, (1997).

9. V. M. Vinokur, T. I. Baturina, M. V. Fistul, A. Yu. Mironov, M. R. Baklanov, C. Strunk, Nature, 452, 613, (2008).

10. A. Ohtomo, H. Y. Hwang, Nature, 427, 423, (2004).

11. S.V. Nikolaev, K. N. Yugaj, GETF, 129, 371(2006).

12. P. S. Laplace, Celestial Mecyanics, 4. (Chels. Publ., Bronks, New York, 1966).

13. M.P. Slavinskij, Fiziko-himicheskie svojstva elementov. (Izd. "Cvetnoj metallurgii", Moscow, 1952), 763p. (М.П. Славинский, Физико-химические свойства элементов. (Изд. "Цветной металлургии", Москва)) [In Russian]

14. A.S. Davydov, Teoriya tverdogo tela, (Nauka, Moscow, 1976), 639p. (А.С. Давыдов, Теория твердого тела, (Наука, Москва, 1976)) [In Russian]

15. M. Somayazulu, M. Ahart, A.K. Mishra, Z.M. Geballe, M. Baldini, Y.Meng, V.V. Struzhkin, R.J. Hemley, Phys. Rev. Lett., 122, 027001, (2019).

16. Ya.F. Ugaj, Fazovoe ravnovesie megdu fosforom, myshyakom, surmoj i vismutom, (Nauka, Moscow, 1989), 233p. (Я.Ф. Угай, Фазовое равновесие между фосфором, мылияком, сурмой и висмутом, (Наука, Москва)) [In Russian]

17. A.N. Doroshenko, Thesis, Kharkov, (2019), 184 p. [In Russian]

18. K. Malik, D. Das et all., J. Appl. Phys., 112, 083706, (2012),

19. D. Stauffer, A. Aharony, Introduction to Percolation Theory, (Taylor and Francis, Washington, 1992), 127p. 